\title{
Why is Co-management of Parks Not Working in Johannesburg?
}

\author{
The Difficult Reframing of State Mandate and Practices in the Post- \\ Apartheid Era
}

\author{
Claire Bénit-Gbaffou
}

\begin{abstract}
Johannesburg City Parks and Zoo (JCPZ) has affirmed its strong redistributive objective in post-apartheid Johannesburg, with the rapid development of new urban parks in former black townships. However, its operational budgets have remained limited in the face of the many pressing housing and infrastructural needs. Many park users, especially in formerly white (and still middle-class) suburbs, have resorted to forms of neighbourhood or community management to compensate for JCPZ's absence. JCPZ is attempting to rebuild its mandate with regards to these public spaces, developing various policy instruments in response to the involvement of park users in the management of urban parks, but also to formalise that involvement. This chapter traces the genealogy of these policy instruments in the making, caught between multiple logics where neo-liberal pressures and models, regular engagements with park users marked by contested legitimacies and racial tensions, and the broader municipal redistributive agenda shape the way in which the post-apartheid state redefines its mandate. The chapter argues that the specific social and racial configurations in which these partnerships are framed on the ground are used by municipal officials to resist transforming their own practices towards more participatory and democratic processes of co-production of parks. The chapter reflects on shifting state mandates in urban governance in contemporary cities of the South and analyses policy instruments crafted for the complex task of formalising and regulating state-society co-production of urban services in the field of park management.
\end{abstract}

\section{Preamble-A (Usual) Scene in a Nature Reserve Joint-Management Forum in Post-apartheid Johannesburg}

In April 2017, I attended (as I have been doing for about one year) the monthly Klipriviersberg Nature Reserve Forum meeting in Johannesburg, which brings

(C) CLAIRE BÉNIT-GBAFFOU, 2018 | DOI:10.1163/9789004387942_006

This is an open access chapter distributed under the terms of the prevailing CC-BY-NC License at the time of publication. 
together representatives of the several civil society organisations (csos) interested in the reserve and the one City Park official in charge of nature reserves in Johannesburg. The meeting's agenda seemed innocuous, with classic items (approval of minutes and management and security issues); there was a relatively low attendance: about ten members of civil society (a majority of old, white, middle-class males, with a passion for and an interest in the environment and the reserve) and one (black, younger, male) City Parks' official. Tensions had been ongoing for several years between these cso members and City Parks (Baloyi et al., 2015; Mokgere, 2016), which had led to the establishment of the Forum - an exception in the management of parks and nature reserves as City Parks does not have the resources to commit its officials to monthly meetings with park users for the 2,500-odd parks and reserves falling under its responsibility.

The meeting turned aggressive, with members of the Forum pointing fingers at the City official and publicly humiliating him with explicit accusations of dishonesty and lies. The conflict crystallised around two issues. The first was the presence of horses and their stables in the reserve. The stables had been informally accepted by csos and City Parks a decade before, on the understanding that the horse owner would patrol the reserve and contribute to its maintenance in exchange for being hosted on site and allowed to offer horse riding in the reserve. This agreement was now contested by the csos as the previous owner had stopped patrolling the park and had sold his horses to a new owner. The official, however, showed reluctance to terminate the agreement, and was accused of delaying the eviction process. The second issue was around the opening of a coffee shop at the main entrance of the reserve, in a City Parks' facility that had so far been made available free of charge for csos' meetings. The cso members accused the official of commodifying the park, and of acting by stealth as the matter had not been discussed within the Forum.

The official's own view was that a coffee shop was important to render the facility more user-friendly, and to garner resources for the park's management. He confided (to me) that several user groups had been selling drinks informally to visitors coming for guided tours and that he had approached each of them to ask if anyone was interested in manning the shop; so, in his view, everyone was

1 This research is part of a broader research programme on 'Practices of the State in Urban Governance', funded by the South African National Research Foundation. It involves individual research (interviews, participant observation in meetings, research-action through the facilitation of workshops with park user groups and City parks officials), as well as collective research (facilitating class projects, mentoring postgraduate research reports: these are referenced in the text), on the governance and management of parks in Johannesburg. 
aware of the move. Similarly, for him the horse riding activities were welcome in the reserve, making it more attractive and potentially generating income whilst opening access to a wider range of environmentally oriented activities. But the City Parks' official never stated his opinions in the meeting. Rather, in the face of these accusations he remained silent, did not defend his views publicly, and appeared to agree with all what was 'suggested' (that he was to write a letter in order to evict the horse owner and that the process of renting the space in question to an entrepreneur was to be revisited). After the meeting, though, he confided to me that he would do nothing of the sort. He would continue formalising agreements with the horse owner and the coffee shop owner as this was best for the reserve. When I asked him why he had not defended his views in the meeting and why he had not discussed these developments in the Forum, he replied that he was tired of seeing all his initiatives being blocked or torn down in these meetings. He would continue regardless, as he was confident he had the mandate and power to do so.

Throughout this meeting I felt deeply embarrassed by the public humiliation I was witnessing - no matter how right the park users' representatives were about incorrect process and lack of dialogue. The tone of the accusations, the configuration of the argument (one single black man alone against a resourced white collective), the finger pointing, the loss of face-all were almost unbearable, perhaps more especially in a post-apartheid context. I was also puzzled about the function of the meeting: the forum had become a space for 'problem-making' rather than a problem-solving arena. Like the official, I saw the two contested initiatives as potentially beneficial to the reserve (if properly managed), and therefore potentially able to achieve consensus within the Forum. It did not seem impossible to formalise horse riding activities and a coffee shop to service an underused reserve and to negotiate their contribution to the maintenance of an undermanned reserve-especially as underuse and lack of management resources are constraints that the Forum acknowledges and struggles with. So, how was this joint management forum leading to the growth and consolidation of contention and the blocking of any initiative or development, instead of collectively building on activities that could easily be framed as beneficial additions to the reserve?

The history of this conflict, the involvement of individuals from both sides in what have become personalised attacks, and the micropolitics of this forum (including deeply entrenched and tacit racial tensions that perhaps limit the ability to find a common language), have been documented elsewhere (Baloyi et al., 2015; Mokgere, 2016). Beyond the specifics of this case, I wondered why the official did not feel an interest, the need, or an institutional motive to solve the issue, rather than leave the conflict to inflate, explode and 
ultimately destroy the forum. Why did he use an 'exit' rather than a 'voice' strategy (Hirshman, 1970)? Why did he act on his own, by stealth, rather than confronting the group and confidently asserting City Parks' mandate: mobilising resources and increasing and diversifying access and use? I therefore sought to analyse the policy instruments guiding the practice of joint park management, and the resources officials could garner to respond to mobilised, and at times demanding, park user groups.

More broadly, this chapter aims at assessing to what extent state practices are challenged and reframed through interaction with civil society in the provision of public services, in a context where parks and their management are given low political and budgetary priority at the municipal level. Through an interrogation with regard to how community engagement is framed as a municipal objective within City Parks, and how tools for guiding these engagements are crafted, I wish to interrogate how the state's mandate is redefined in contemporary cities of the South. I will reflect on the challenges the state faces in its attempt to regulate what is by definition highly informal and unstable: community engagement in park management. The chapter's ambition is therefore both theoretical and empirical - contributing to understanding contemporary statecraft (through the lens of officials' practices in the joint management of urban parks), debating the challenges of governing public spaces in contemporary cities, and reflecting on the meaning of 'postapartheid' today.

The first section of the chapter borrows from different theoretical fields (participation, neo-liberalisation and coproduction) to conceptualise how the study of the joint management of parks can lead to an understanding of the dynamics of statecraft. The second section reviews the policy instruments developed by City Parks to frame community engagement around park management and reflects on the conflicting state rationalities they embody and they construct, in the context of post-apartheid Johannesburg.

\section{$2 \quad$ Co-production of Park Management-Between Neo-liberalisation, Democratisation and Pragmatic Service Delivery in Cities of the South}

This section considers a variety of theoretical approaches in order to make sense of the joint management of parks, as public spaces, in contemporary cities. It discusses the relevance and limitations of theories around community participation, neo-liberalisation, and co-production of urban services in cities of the global South. 


\section{$\mathbf{2 . 1}$}

\section{Joint Management of Parks as Community}

\section{Participation -Empowerment or Exploitation?}

The involvement of park user groups in the shaping of public or collective urban spaces has long been studied and understood under the framework of community participation, as a right embedded in conceptions of urban citizenship, empowerment, and local democracy, where the public at large is legitimately expected to be able to influence the design and management of the urban spaces it uses. This literature has for some time debated whether participation was a tool of empowerment and democratisation emerging from below, that should be advocated and nurtured, or a tool of oppression and manipulation in the hands of public authorities, that should be distrusted and rejected (Cooke and Kothari, 2001; Williams, 2004). This dichotomy has somehow been overcome, with attention paid to the multiple facets of participation (contrasting invented with invited spaces of participation: Miraftab, 2004), an emphasis on the unpredictability of outcomes (Cornwall, 2008), analytical tools for analysing the micropolitics of public meetings (Cornwall, 2007; BénitGbaffou and Mkwanazi, 2012) and an exploration of conditions for empowerment even in the most institutionalised participatory platforms (Williams, 2004). A second debate marks this field of the literature, one perhaps less visible and resolved: how to measure the degree and nature of community participation? Several tools have been developed, the most famous being Arnstein's 'ladder of participation' (1969), focusing on the degree of power vested in the citizens, starting from lower degrees (tokenism) and going towards higher degrees (full control) of citizen's empowerment. But these tools mostly focus on processes of decision-making and are of lesser relevance when it comes to assessing the outcomes of community participation and the difference that it makes with regard to the actual content of the policy, form of the urban space, or outcome of the project built. ${ }^{2}$ Besides, by normatively affirming the primacy of 'citizens' control', the ladder is implicitly assuming the illegitimacy of the state's vision, adopting a suspicious take on the State typical of the postmodern and postcolonial era. It is a contrario celebrating the legitimacy and intrinsic progressiveness of community views. This posture has been criticised theoretically and practically, in contexts where participation spaces are appropriated exclusively by middle-class groups to further their already existing privileges (Bénit-Gbaffou, 2007), where mass movements adopt exclusionary and violent behaviour against local social groups defined as 'outsiders' (Glaser, 2015), or

2 This interrogation on outcomes is shared by social movement studies (Giugni, 1998), but it has possibly not led either to significant analytical progress, theoretically or methodologically. 
even more generally where a complex politics of scale opposes legitimate but narrow local claims to looser but broader public benefits (Purcell, 2006).

Coming back to the state's assumed illegitimacy, participatory literature is generally entrenching a deep suspicion around public intervention. This suspicion stems from the postmodern critique of the state, assumed (or at least likely) to be oppressive; the united and obvious 'antagonist' or 'enemy' in urban governance that needs to be constantly checked, tracked, resisted or challenged; or the machinery incapable of grasping the complexity and fluidity of society, especially when it is developing multiple strategies of resistance (Scott, 1985). Participation theories are therefore often ill-equipped to unpack state practices. They fail to see the state not only as a heterogeneous and complex organisation (Gupta, 2012), but also as a potentially developmental agent, with legitimacy not only in partnering but sometimes also in countering, or at least reshaping, claims emerging from not always progressive or visionary, at times parochial and conservative, local civil societies. However, this view of the state as potentially sinister in its agenda and control apparatus is starting to be challenged, especially from intermediary countries, such as Brazil, India and South Africa - where states affirm, and resource with some capacity, strong redistributive agendas in highly unequal urban societies.

Some theoretical tools are more balanced in their understanding of civil society's versus the state's different objectives and rationalities when embarking on community participation. Pretty's typology (1995, adapted in Cornwall, 2008) usefully places participation in a continuum between a managerial objective (facilitating project implementation and public-space maintenance through community buy-in) and an empowerment objective (resourcing civil society to shape urban spaces and partake in decisions that affect its environment). Both objectives are legitimately shaping actual processes of participation, in a constant negotiation and balancing act. This approach can be found, usefully for our object of research, in Jones' (2002) model of cycles of engagement between municipal officials and user groups, expressed in his case study of joint park management in the UK. Jones writes from a policy context where British municipalities are required to partner with civil society organisations to lead projects and manage public assets (due to shrinking public funding and as a condition for accessing public grants). Based on observation of interactions between officials and park user groups ('Friends of the Park'), Jones investigates what is required from officials to support both successful joint management of parks and interaction with those groups. He suggests different skills, resources and objectives in what he analyses as different steps in the relationship (from complaints and distrust, to constructive relationships around small practical objectives, to enhancing autonomy and the 'responsibilisation' of park user 
groups). The limit of his approach is that he does not unpack the state muchit is represented and encapsulated by one single municipal official in charge of community engagement, without placing this official in a set of policies, budgets, official norms and rules, specific policy instruments and their politics.

Beyond the field of participation studies, other layers of critique, stemming from similar conceptions of the state as potentially driven by a sinister and oppressive agenda, and of the state as relatively unitary, have developed in the vast array of theories critiquing processes of neo-liberalisation. This literature, inspired either by Foucauldian or by neo-Marxist analyses, helps 'complexifying' the theorisation of the state in ways that are useful for our purpose.

\section{2 \\ Critical Theories of Neo-liberalisation-Joint Park Management as 'Rolled-Out' State or as 'Realist “Governmentality"'}

Foucauldian-inspired analyses of neo-liberal governmentalities see participation as a relatively recent dispositif of power leading participants to internalise and naturalise the policy choices driven by other interests, and partly overlapping with theirs (Roy, 2009; Morange, 2015; Rosol, 2015). Rosol (2015) however departs from an assumed suspicion of the state, unpacking the recourse to participatory tools as a state strategy for overcoming residents' opposition to its spatial planning objectives (densification and compaction of the city in Vancouver), without assuming these state objectives are illegitimate. The state's intervention and use of dispositifs of governmentality (though sets and techniques of participatory engagements), she argues, have on the contrary assisted in overcoming and reshaping civil society's conservatism and parochialism. She usefully proposes the concept of 'realist governmentality' mingling deep participatory processes (where residents' concerns are considered and answered, if reframed) with forms of neo-liberal governmentality (where residents are confronted with existing budgetary constraints and required to make choices in such contexts). Her focus on participation as a tool of government intervention, analysed as realist governmentality, is helpful for our unpacking of state practices of community engagement in parks.

Going further in unpacking policy instruments, MacKinnon analyses the effect of key performance indicators (KPIS) on officials' practices in the provision of public service (MacKinnon, 2000). He argues that while the KPIs are an efficient tool of administrative control (in particular the control of the local level by the central level of the state), officials often retain a degree of agency and choice. This agency leads either to 'colonisation' (the reshaping of sets of practices alongside the KPIs) or to 'decoupling' (the development of two parallel sets of practices as resistance to control) in organisational responses to this neo-liberal management tool. Hibou (2012) is more pessimistic, showing 
how 'public goods' typically cannot easily be quantified, and how the control of officials' practices, through a quantitative measurement of their outputs, essentially marginalises and destroys the very spirit of public service.

Neo-Marxist analyses also interrogate state restructuring in several ways. They analyse the 'rescaling' of the state and the 'geographies of actually existing neoliberalism' in various parts of the world (Brenner and Theodore, 2002). They thereby enrich analyses of the state as a multi-layered, multi-scalar organisation with potentially competing agendas and dynamics that are locally embedded. These studies also nuance the hypothesis of the state's 'roll-back' (withdrawal from certain functions and mandates that used to be public) with explorations of state 'roll-out' dynamics-where it delegates some of its functions to non-state agents, through a variety of agreements, to provide public service (see also Hibou, 1999). Research directions stemming from this approach are multiple. Some critically analyse partnerships, unpacking the effects of the privatisation of service provision on social and spatial equity for instance (Graham and Marvin, 2001). Others examine the blind spots of neoMarxist and Foucauldian perspectives on state practices, interrogating the circulation of policy ideas across scales of the state and between state and society (Uitermark, 2005). Others interrogate service providers' working conditions, rendered precarious under a multiplicity of scattered and temporary service provision schemes (Miraftab, 2004; Krinsky and Simonet, 2017).

Krinsky and Simonet, in particular, examine the question of 'who cleans your park' in contemporary New York. Through an ethnography of the various agreements with an array of temporary workers, social programmes, volunteers and interest group and NGO members, they show how these fragmented resources have come to replace the coordinated municipal service that used to manage public parks, to the detriment of service provision, workers' rights and spatial equity. Rosol $(2010,2012)$ looks, rather, at the social dynamics leading to the consolidation of user groups for the management of neighbourhood parks ('community gardens') in Berlin. Coming back to classic debates within the participation literature on whether citizens' involvement in the management of parks is the expression of alternative urban citizenry or the ultimate neoliberal tool with which the state withdraws from its responsibilities, she concludes that both dynamics shape the new way in which neighbourhood parks are managed. She argues that temporary and locally constructed arrangements emerge as forms of citizens' mobilisation, and then tend to become institutionalised thanks to the broader (neo-liberal) acceptance that the state needs to delegate tasks of service provision to non-state agents (Rosol, 2012). She advises (Rosol, 2010), usefully for this chapter, that the fluid and ad hoc nature of these local arrangements require careful examination and tracking, and calls 
for suspending the strong normative assumptions attached to both participation and neo-liberalisation theoretical approaches (the former being seen as progressive and desirable, the second as regressive and to be avoided). However, this tracking focuses more on community dynamics, their links to social movements and their forms of institutionalisation than it equips us with conceptual tools with which to unpack state practices and the state's changing mandate.

\subsection{Joint Park Management as Co-production: Shifting State and Citizens' Mandates through the Co-Production Process?}

Understanding the shifting definition of statehood could be argued to be the focus, although often implicit and intuitive, of the literature on the co-production of public services. This concept stems from experiences of service delivery in developing cities in the 1970s (Ostrom, 1996; Turner, 1976) and is re-emerging in contemporary debates attempting precisely to suspend for one moment the normative assumptions attached to notions such as partnerships, seen through the critical lens of neo-liberalisation theory. Ostrom (1996) interestingly conceptualises co-production as a process of joint production of public infrastructures or services, by state and non-state ${ }^{3}$ stakeholders. What is interesting in the cases she describes is the way in which both citizens and state officials transform their practices in the process of the production of services. Both adapt their practices in order to coordinate with and complement the others' in intertwined processes. Differently from the concept of partnerships (where each partner is generally defined with set resources and actions that they will bring to the deal), the notion of co-production emphasises the process of the joint and mutual redefinition of mandates. It allows for an open and dynamic definition of needs, claims and preferences (Stone, 2006), but also of skills, priorities, types of intervention and modes of action.

Joshi and Moore (2004), discussing Ostrom (1996) from the explicit perspective of the global South, interrogate the state more centrally. They argue that co-production, as 'unorthodox public service delivery in challenging environments', is the norm in most countries and cities of the global South. But, unlike Turner (1976), who contrasts self-help housing provision with state responsibilities, they unpack the interactions between state and non-state agents engaging in service provision. Doing so, they avoid taking normative positions - in terms of governmentality (often seen as the manipulation and disguised oppression of society by the state) or in terms of neo-liberalisation (in terms of the subjugation of society to the logics of economic profit alone).

3 She considers civil society as the main non-state co-producer in her paper. 
The authors argue that both framings are partly ill-fitting in Southern contexts, where the state actually never provided any services in certain areas or sectors of society. Therefore co-production is rather seen as an extension, not as a shrinking, of the state's intervention in society (Hibou, 1999; Jaglin, 2008). This is particularly relevant for this chapter, as the state never provided for urban parks in most of the urban areas (e.g. the black portion of South African cities - the majority of its population) and the post-apartheid regime led to an extension of the scope and scale of state intervention. Co-production is also seen as the process of constructing practical and largely context-dependent collective solutions: not necessarily as driven or controlled by the state, at least not as an assumption, leaving some of the process open. This too seems relevant for the purposes of this chapter, where-rather than a situation of state roll-back or even roll-out - the current situation would be more adequately described as the expansion of state authority. In Johannesburg, park users in middle-class areas in particular have taken over the actual management of parks since the turn of the millennium, and City Parks is looking for ways to reestablish its mandate with regard to public-space management-with limited financial and human resources - and simultaneously attempting to capitalise on the mobilisation of civil society resources.

The benefit of this approach is double: it interrogates the shifting, contested and redefined mandates for the state in state-society relations understood as dynamic. And it analyses how these processes impact on the actual provision of services and production of spaces in the city, through an attention to the technicalities involved in the provision of services and their negotiation (Watson 2014). In this way, it links the materiality of instruments (in their own, sector-specific, technical logics, responding to practical challenges but also caught in their own functional dynamics) to state rationalities and the state's shifting, unstable and contested mandates. Focusing on the process of defining such instruments, as lenses illuminating both internal and external contestations contributing to redefining the state (Uitermark, 2005), it borrows from a Foucauldian approach (Lascoumes and Le Galès, 2007). But it also attempts to respond to frustrations with Foucauldian approaches by interrogating the effect of these techniques on the production of the city itself, the way they affect the making of urban services and spaces (here urban parks and their actual management) through their own functional and technical logics. This is in line with Stone's suggestion (2006) to look at 'power to' (shape the city and produce urban spaces, along a vision that is built and shared by coalitions of actors mobilising resources for its implementation) rather than only at 'power over' (questioning forms and processes of influence and domination). In this respect, the co-production approach might assist in rejuvenating our thinking about the state, its practices and its mandate in the contemporary city of the 
South. It helps us interrogate actual processes of production in relation to shifting mandates by twinning the study of technical instruments (that are sector-bound and produce specific effects on the city) and the analysis of the processes of state-making.

The risk with approaches in terms of co-production-and their suspension of the normative judgements brought about by the neo-liberalisation critique or the governmentality approach-is the marginalisation of the critical interrogation of social and spatial inequality, on the one hand, and of power dynamics on the other (Watson 2014). Arguably however, adopting the lens of co-production does not prohibit an interrogation of inequality, nor an analysis in terms of power dynamics. The redefinition of state-versus-society mandates and prerogatives is a deeply political and contentious process in which these issues actually come to the forefront. As for urban parks in Johannesburg, the question of transformation (addressing past and present inequalities, especially in their socio-racial dimension) is at the forefront of City officials' mandates, discourses and preoccupations; the contestations in the processes of co-production are testimony to the deep political nature of these engagements.

The analysis of which rules are negotiated to regulate public spaces (parks in this case) and how they redefine the boundaries of the state remains underdeveloped. Ostrom (1996) interrogates explicitly, analytically and normatively the rules to regulate 'the commons' (based on observations of a multiplicity of case studies), but she steers away from analysing the respective and shifting mandates of society and state, focusing predominantly on rules negotiated within civil society to establish systems of self-regulation (less central to our objective here). We are still to theorise on how forms of the co-production of public services (rather than autonomous, citizen- or private-led provision) affect, challenge and shift the practices, the mandate and the nature of the state in contemporary cities of the South.

\section{Unpacking the Objectives of 'the State' through Policy Instruments for the Management of Parks: Rise or Marginality of Co-production as Form of Service Delivery?}

This section interrogates the state's practices and objectives through the lens of co-production in order to investigate why practices of the joint management of parks fail to work in post-apartheid Johannesburg, in spite of what could be considered favourable conditions for their emergence and consolidation. These favourable conditions are: firstly, the existence of park user groups with some experience in park management, at least in middle-class areas; and secondly, a policy framework for City Parks that seeks improved relationships 
with users to address the negative image marking the municipal agency, and that aims at mobilising complementary human and financial resources in the context of scarce public funding for parks.

Through the analysis of various policy instruments, it is argued that genuine engagement with communities to deepen the accountability and responsiveness of the state is not a priority objective for City Parks compared to the need to garner financial resources. Secondly, the mandate and responsibility to engage with communities is actually scattered across the agency and contested between different units and officials, with a gap between those actually on the ground and confronted by user groups and those officially in charge of community engagement. Thirdly, developing actual partnership guidelines that foster the co-management of parks is seen as a challenge by City Parks' officials - both technically and politically. It seems much easier to delegate the management task to non-state institutions or to build partnerships with the corporate sector, where the terms of exchange are simpler and clearer (for instance, where the corporate sponsor is branded, in exchange for its financial contribution); avoiding the legal and political issues of joint fundraising or staff management. These guidelines are all the more difficult to imagine and develop, given that where joint management forums do exist (and could provide an opportunity to experiment) they are mostly found in former white, middle-class suburbs without the political legitimacy necessary to act as real 'partners' for the City. In these joint management forums, contentious and vocal user groups are easily ignored by City Parks, which often considers them to be inspired by parochial attempts to reproduce racial and social privilege, in the (middle-class, suburban) areas that are not its priority.

\section{1 \\ Community Engagement-Framed Mostly in Neo-liberal Terms in Policy Instruments}

The 2013 institutional restructuring of City Parks, a municipal agency reframed as Johannesburg City Parks and Zoo (merging a deficit-prone entity, City Parks, with a profit-generating one, Johannesburg Zoo), was also the occasion to align the agency with new public management principles. This alignment (see Figure 5.1) illustrates the importance of auditing processes emphasising costeffectiveness and financial monitoring; it created a legal and contract management arm, and multiplied dedicated units aside from service delivery (still defined as 'core business'): marketing, public relations, and new business development inter alia.

Looking at community engagement within this organogram reveals how scattered the agency is (Bosaka, 2015; Bénit-Gbaffou, forthcoming). The official task of liaising with communities lies with Stakeholder Liaison Officers (sLOs) working in Stakeholder and Public Relations Management—and their main 


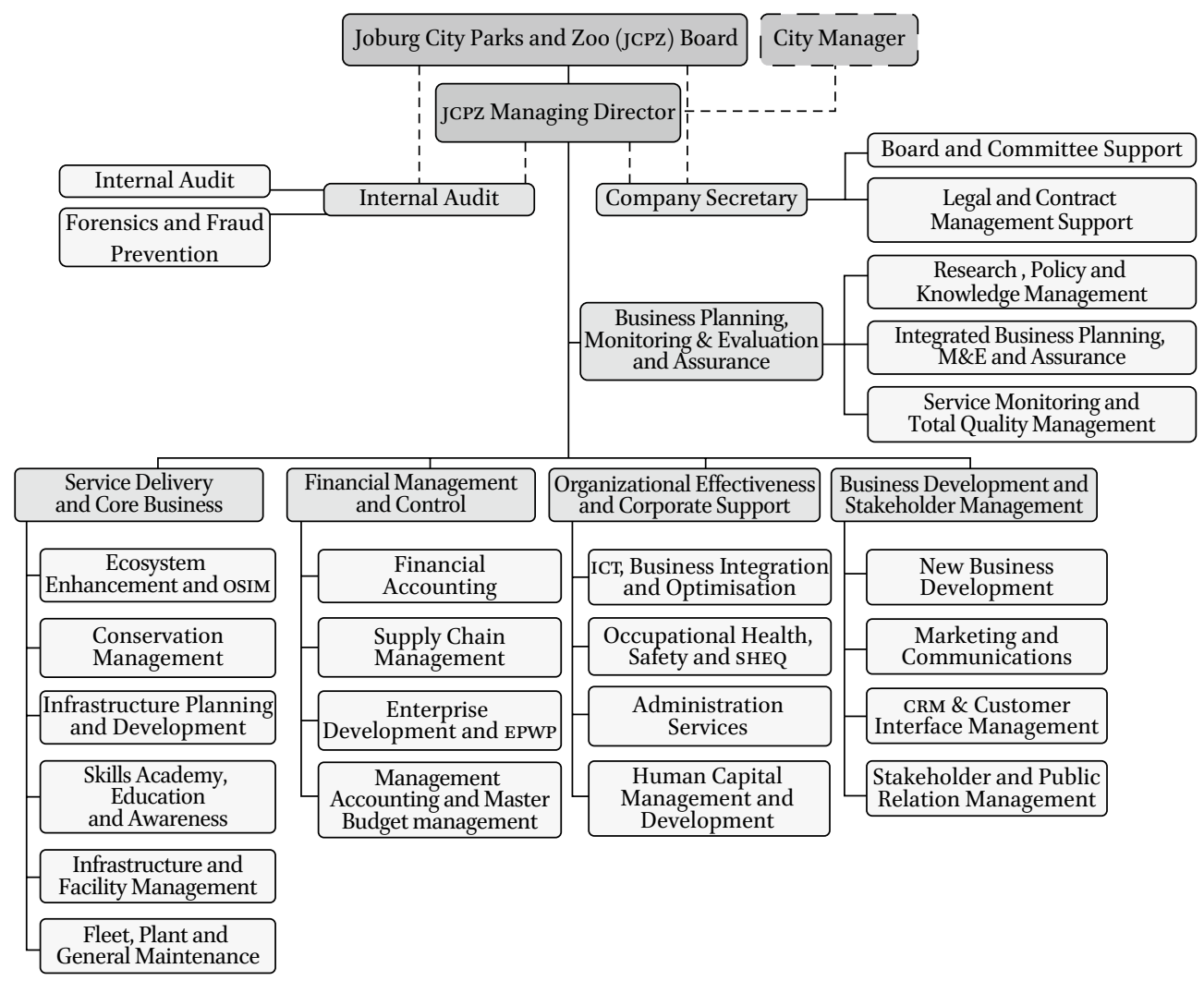

FIGURE 5.1 JCPZ organogram, 2013. Recommended level 3 positional structure. SOURCE: JCPZ (2013A)

objective is to defend and protect City Parks' reputation and avoid conflict, bad publicity and reputational damage. The function of Customer Interface Management was never consolidated in a department; rather, it has been tasked to the regional managers (under Service Delivery and Core Business), whose Key Performance Indicators include measurement of users' complaints and the rapidity of their responses to these complaints. Other officials in charge of community engagement are situated under New Business Development, which is about fundraising for the City or the agency through events organised in parks ${ }^{4}$ and partnerships established with donors, mostly from the corporate sector. A third type of community engagement is effected by officials in charge of Education and Awareness, who develop educational campaigns and partnerships with township schools in particular, with regards to behaviour

4 Which City Parks actually does not benefit from, as the event fee goes into City of Johannesburg coffers. 
management (respect for public assets and the park) but also to introducing environmental education to groups that have been deprived of access to green open spaces. The fourth type of engagement with the public falls under the management of outsourced services and the distribution of minor jobs (Supply Chain Management, Enterprise Development, and EPWP ${ }^{5}$ ). The latter programme in particular (EPWP) constitutes a key element of the interaction between JCPZ and residents in townships and informal settlements, as it is used to distribute piece jobs and stipends to the unemployed in disadvantaged areas and groups.

Community engagement, or rather 'Stakeholder Management' is therefore mostlyseen as a branding and marketing, public relations exercise-responding to crises when organised user groups become too vocal or threatening, but not addressing the fundamental causes of complaint: insufficient operational budgets and human resources to cater for the 2,500-odd open spaces that JCPZ is responsible for. The objective of mobilising resources is framed mostly in terms of garnering financial contributions from the private sector (rather than seeing community involvement in park management as a 'resource') and developing new business opportunities. This is done through big corporates branding themselves in exchange for financial contributions to events, infrastructure, or management, or through small emerging black enterprises and cooperatives given short-term contracts by City Parks. These contracts are actually a way for JCPZ to mobilise financial resourcesfrom other branches of the state - the national state through EPWP, or the municipality at large through Jozi@work programmes. ${ }^{6}$

This framing — which could be termed neo-liberal—however coexists with a strong redistributive discourse (JCPZ, 2013a) focusing on opening new parks in disadvantaged areas (former black townships and informal settlements) and bridging the 'green divide' between the 'leafy suburbs' to the 'dusty townships'. This discourse is not mere rhetoric and is matched by important capital budgets that go each year to marginalised areas and the active development of new parks - with no increase, however, in operational budgets for the management of the agency's growing assets and only low levels of community engagement

5 The Expanded Public Works Programme (EPWP) consists of stipends given to disadvantaged individuals for community work for a short period of time (one to three months). The programme is funded by the national government and in Johannesburg is used mostly by municipal entities such as City Parks and Pikitup (waste management). Based on a critique of the limited developmental impacts of EPWP, Johannesburg Mayor Parks Tau developed a City-funded programme, Jozi@work, that organised service delivery contracts between municipal entities and cooperatives (contracts for a period of three years, including training by the municipal entity contracting the cooperative)—distributing more stable employment on more collective terms. However, the programme was terminated during the tenure of Democratic Alliance Mayor Herman Mashaba in 2017.

6 See previous footnote. 
in contexts where there has been limited historical opportunity for the consolidation of local park user groups. The emphasis on the capital budget also means that funding for the outsourcing of various tasks (including management ones) is easier to mobilise than that for hiring supplementary staff, for which operational budget is direly lacking in the agency.

Community engagement, even in its many ambiguous meanings and dimensions, is therefore a rather marginal and certainly quite implicit policy objective, as illustrated by the ten strategic Key Performance Areas for the agency (see Table 5.1). However, it is also clear that the neo-liberal framings (lack of

TABLE 5.1 Ten strategic Key Performance Indicators for JCPZ

\section{Ten Strategic Key Performance Areas Key Performance Indicators}

\begin{tabular}{|c|c|}
\hline 1. Financial balance & $\begin{array}{l}\text { Value (rands) of external funding } \\
\text { collected }\end{array}$ \\
\hline 2. Food security & $\begin{array}{l}\text { Number of community gardens } \\
\text { created }\end{array}$ \\
\hline 3. Active citizenship & $\begin{array}{l}\text { Number of public workshops in } \\
\text { environmental education }\end{array}$ \\
\hline 4. Sustainable city & $\begin{array}{l}\text { Number of projects linked to } \\
\text { 'Corridors of Freedom** }\end{array}$ \\
\hline $\begin{array}{l}\text { 5. Partnerships with external } \\
\text { stakeholders }\end{array}$ & $\begin{array}{l}\text { Number of service level } \\
\text { agreements signed with external } \\
\text { partners (other municipalities, } \\
\text { universities, sponsors) }\end{array}$ \\
\hline $\begin{array}{l}\text { 6. Small Micro and Medium } \\
\text { Enterprises (SMMEs) }\end{array}$ & $\begin{array}{l}\text { Number of training workshops } \\
\text { for SMMEs }\end{array}$ \\
\hline $\begin{array}{l}\text { 7. Small Micro and Medium } \\
\text { Enterprises (SMMEs) }\end{array}$ & Number of EPWP jobs created \\
\hline $\begin{array}{l}\text { 8. Small Micro and Medium } \\
\text { Enterprises (SMMEs) }\end{array}$ & Number of cooperatives created \\
\hline $\begin{array}{l}\text { 9. Small Micro and Medium } \\
\text { Enterprises (sMMEs) }\end{array}$ & Number of cooperatives trained \\
\hline 10. Green space development & $\begin{array}{l}\text { Number of hectares of green } \\
\text { space created }\end{array}$ \\
\hline
\end{tabular}

\footnotetext{
* The 'Corridors of Freedom' is a mayoral flagship programme that identifies four 'corridors' in the city where transport infrastructure and other public and private investments are to be concentrated in order to 're-stitch' the post-apartheid city.

SOURCE: JCPZ, 2014.
} 
human and financial resources to manage parks) and discourse (increasingly pressing requirement to raise complementary resources to manage parks) also open opportunities for various forms of community involvement in the management of parks - not principally through fundraising (although this is one dimension in the wealthier neighbourhoods), but mostly through human resources: voluntary work, individual or collective, addressing the everyday issues of park management in the absence of dedicated municipal staff for each park. Indeed, each park manager has under his or her responsibility up to 70 public open spaces (developed parks, undeveloped parks, conservancies, and nature reserves) for which he or she manages small teams of between 15 and 30 horticulturists, rotating them between parks according to a tight service roster. $^{7}$

\subsection{Engaging with Communities: Competing and Contested Mandates for Street-Level Officials}

Park managers, as the only City officials regularly (if insufficiently) 'on the ground', serve as the de facto liaison between the agency and park users: everyday operational challenges require a degree of interaction with surrounding communities and being onsite makes them the complaint desks for local users. How to have the team of horticulturists cut the grass in the park, when it has two hours to do so before moving to the next park, if there is litter on the grass that has not been collected by the municipal agency in charge of litter collection (Pikitup), or when that litter is regularly deposited by anonymous users in sections of the park that could be described as 'border vacuums' (Jacobs, 1961)? What to do when groups of homeless people sleep and live in the park, sorting out the waste they want to recycle and sell and leaving litter in the park, when residents complain, and when police evictions only lead to these homeless groups coming back a few days later? Park managers, in practice, engage regularly with users and user groups, but they have no mandate to do so, generally no professional training for such interactions (although they often have learnt by doing), and limited resources and back up with regard to the solving of issues. In the Klipriviersberg Nature Reserve Forum, for instance, the official sitting in the meeting is the Head of Conservation; he has environmental training and a passion for birds, and expresses an explicit dislike for the politics of community engagement.

Park managers report directly to regional managers, whose Key Performance Areas (KPAS) relate - to a significant extent (45 per cent) - to the number and importance of park users' complaints within their administrative region, as

7 Parks get serviced between once a week and once a month depending on their status, size, and use, but also their spatial and political visibility. 
well as to the rapidity with which they solve the issues that led to the complaints. However, the other KPAs and the bulk of park managers' job is to manage the scarce staff rotating between parks, track their movements and the time spent in each park, tick their scorecards and manage staff scarcity (Table 5.2). This leaves limited time to engage in solving the issues that lead to complaints, which generally have complex and structural causes and require long-term engagement with users and local contexts rather than quick fixes.

Those with an official mandate, the Stakeholder Liaison Officers (SLOs), do not attend any user group, residents' association or civil society organisation meetings, even if City Parks is officially invited to these meeting and its presence is crucial to respond to users' issues. It is only when there are major crises, such as the one in Klipriviersberg Nature Reserve (involving the media and the

TABLE 5.2 Summary of Key Performance Indicators for JCPZ Regional Managers, 2017

\section{Key Performance Area (KPA), Key Performance Indicator (KPI) park regional managers (2017)}
1. Financial sustainability and resilience $(20 \%)$

2. Customer perspective (45\%)

3. Internal business

processes $(23 \%)$

4. Learning and growth $(12 \%)$
Percentage of General Auditor's findings responded toPercentage of operational budget spent

Number of EPWP and Jozi@work jobs created

Number of cooperatives and SMMEs engaged in programmes (Jozi@work)

Annual Customer Satisfaction

IndexPercentage of resolution of customer complaints

Number of complaints received over 30 days

Targeted turnaround time per maintenance cycle, for various types of parks (flagship, developed, undeveloped parks, etc.) Number of mature trees actively maintainedNumber of trees planted and maintained Turnaround time of fallen tree removal Quarterly performance assessment conducted for all direct reports Number of innovation initiatives

SOURCE: AUTHOR'S OWN ANALYSIS, FROM JCPZ DOCUMENTS, 2017A, 2017B AND 2017C. 
possibility of litigation) that they intervene with user groups. Their Key Performance Indicators (Table 5.3) are actually framed around engagement not with user groups, but with ward councillors, as the sole legitimate representatives of civil society at the local level. ${ }^{8}$

TABLE 5.3 Summary of Key Performance Indicators for Stakeholder Liaison Officers, 2015

\section{Key Performance Area (KPA), Key Performance Indicator (K PI)} Stakeholder Liaison Officers

1. Internal business process

Internal engagement with other JCPZ departments and number of meetings attendedInternal coordination and facilitation of departmental programmes such as environmental education, operations, and recruitment of community liaison officers (CLO) Monthly reports, responses to councillor queries

2. External stakeholder perspective

\section{Learning and development}

Number of engagements with councillorsNumber of engagements and joint programmes and campaigns with city, provincial, and national government Number of participants in engagement with organs of civil society, concerned residents, and political parties regarding service delivery challenges Attendance at quarterly Councillor forum Attendance at regional service delivery, Joint Organisation Committee, or Section 79 meetings

Training and development programmes including workshops - one per financial year

SOURCE: AFTER BOSAKA (2015), FROM JCPZ DOCUMENTS, 2015A AND 2015 B.

8 A ward represents around 20,00o registered voters, which could indicate between 6o,00o and 100,000 residents, depending on the ward. 
The narrow definition of 'stakeholder engagement' (defined as engagement with councillors as local brokers with communities) is explained first by the extreme lack of resourcing of the unit: only four SLOs for the whole metropolitan area and 2,500 open spaces (not all of them having user groups ${ }^{9}$ ). There is no way such a limited staff can attend extremely demanding community meetings, often occurring once a month at late hours and in generally remote and suburban locations where public transport is scarce and dangerous. The narrowness of SLOs' mandate is also linked to the resistance of elected ward councillors, who protect and defend their prerogative as the only legitimate mediators between the City and residents - all the more so because the national legislation on municipal structure has deprived them of any real institutional power, out of fear of fostering racial fragmentation and predatory or violent clientelism (Bénit-Gbaffou, 2008). SLOs therefore complain that they are prohibited from calling any public meeting without recourse to the mediation of ward councillors, whose mobilisation and interest is uneven across the city.

Beyond those street level officials, another area of contestation arises between the official heading the 'Stakeholder Management' unit and the one in charge of 'New Business Development' - the latter theoretically focusing on engagements and partnerships that involve financial transactions (sponsorship or event organisation). However, in practice the lines are blurred, as financial contributions often require a prior process of informal engagement and the building of a relationship of trust, while engagement with communities might lead to fundraising initiatives that financially benefit the park. This institutional blurriness is aggravated by the different professional skills and trajectories of the two officials. The former is a loyal and long-standing parks official defending the image of the agency and its traditional mandate, and seeing communities mostly as a nuisance, a risk, or a challenge; the latter, meanwhile, coming from Johannesburg Zoo, is far more socially aware, builds networks, and is entrepreneurial in spirit.

Whilst there is merit in community engagement not being confined to one single unit or official and being mainstreamed in the institution where various forms of engagement with individual or collective users are acknowledged or encouraged, there is also a lack of clarity regarding roles and mandates on the ground as well as at the high bureaucratic level. This lack of clarity also leads to a lack of proper resourcing, both of those officially in charge of Stakeholder

9 City Parks officials were unable to provide us with a number for (formal or informal) user groups, and had no consolidated list of such groups, dealing with them on an ad hoc basis depending on how vocal they were in their claims, and at times more regularly where user groups were more consolidated. 
Management and of those practically confronted by users and user groups on a daily basis. This might reflect the fundamental ambiguities of City Parks' position on community engagement - a neo-liberal frame confronted with potentially democratising practices that have not been explicitly or actively embraced. The concept of co-production and the changing state practices it entails is still foreign to City Parks officials' conceptions of themselves and their institution, even if co-production practices are developing on the ground.

\subsection{Uncertainty Regarding How to Define and Consolidate the Rules of Co-management}

This gap is visible in City Parks' attempts to formalise partnerships between itself, as the agency mandated for park management by the City of Johannesburg, and park user groups actually involved in the management of specific parks. These attempts are studied through the development process of partnership guidelines as well as formal documents establishing different types of agreements and signed by City Parks and specific non-state agents.

The first document, initiated in 2013, is entitled 'Framework on Stakeholder Partnership Agreement for Joint Natural Resources Management of Natural Areas' and is being developed by the New Business Development unit (JCPZ, 2013b). It attempts to provide generic guidelines for the establishment of joint management committees, bringing together City park officials and park user groups to manage nature reserves - areas larger than parks, less used, and more difficult to maintain due to the specific environmental conservation requirements that the status of nature reserve entails. ${ }^{10}$ This document is currently only a draft, and has not been finalised, consolidated or adopted four years after its drafting — neither has this draft been discussed with stakeholders; it remains blocked due to legal concerns. The first of these concerns is financial. Whilst the partnership is explicitly geared towards mobilising complementary resources for the management of nature reserves, and in particular financial resources, City Parks as a municipal agency is uncertain if it is entitled to engage in fundraising activities jointly with park user groups. In particular, it invokes the 2013 Municipal Finances Management Act as an important obstacle to the possibility of ring-fencing funding raised by the City for a specific park. This Act has been framed explicitly to avoid the local ring-fencing of financial resources for a specific space or territory, in response to the apartheid-era local government structure, which separated resourced and tax-endowed white local authorities from impoverished and tax-deprived black local authorities.

10 In particular, the legal obligation (not followed in parks) to regularly and repeatedly destroy 'invasive alien vegetation', which is seen as a threat to water reserves and to indigenous species-work that is very costly in terms of human resources. 
The Act aligns with the construction of metropolitan institutions to govern cities, inspired by the political slogan popular in the 1980s-'one city, one tax base', rejecting the institutional fragmentation and resource ring-fencing that were central to the reproduction of racial and social segregation. South African municipalities therefore have recourse to various forms of delegated ring-fencing — as mechanisms for raising supplementary resources affected to specific territories - such as City Improvement Districts, or here, park user groups. This delegation, however, means a loss of power for municipal institutions, which have no grasp of the amounts of resources actually collected by those groups, and no influence over how this funding is used. This is the case with park user groups, some of which have been able to garner a substantial amount of funds for the parks in question (through events or campaigns) and have used these funds without necessarily informing or obtaining formal agreement from City Parks to upgrade or develop park facilities. ${ }^{11}$

The development of a joint management committee in the draft framework, therefore, prevents such a committee from actually leveraging funding for the reserve - a major impediment to the consolidation of such joint management in the draft framework. A possible technical solution could be to task the partnering stakeholders to fundraise and report to the joint management committee. But this would entail a degree of trust (that currently does not exist), of reciprocity in disclosing resources available for the park (which grounded officials currently have no mandate for), and also a form of delineation of each partner's mandate and role-currently not developed in the framework. This issue is arguably, although less visibly, the second major obstacle to the consolidation of the framework: uncertainty regarding the definition of the respective roles and mandates of each partner. City Parks indeed appears, in its practices of engagement with park user groups, extremely reluctant to give up sections of its mandate and share decision-making authority on issues affecting the park. How temporary staff (EPWP and Jozi@work) are deployed and coordinated, what events are organised in the park and when, when public interventions are planned, and what budget is allocated for the year are areas of great contention between City Parks and park users, the latter complaining that they are never consulted on nor even informed of these matters, even though they affect the everyday management of the park that they themselves are driving.

11 This has been the case in Zoo Lake, where the user committee has unilaterally revamped a sports field. City Parks has strongly criticised this initiative and frozen the committee for a few years, before the committee was revived with a less autonomous stance (Hadebe, 2015). 
A similar uncertainty is to be found in another, more ad hoc document, a Memorandum of Agreement (MoA) jointly signed by one user group-the Friends of Kloofendal (FroK) - and City Parks (JCPZ, 2015b, 2017c). Interestingly, the document was framed based on an existing interaction between the user group and the Education and Awareness unit. FroK accepted to participate in City Parks' programmes of environmental education for township school children (in the form of ten tours they would provide free of charge annually for about 6o learners each) in exchange for the free use of a City Parks office on site. This agreement, supervised by City Parks' legal department, is however silent on the subject of other management partnerships, in particular everyday practices of the conservation manager and the user group-in terms of invasive alien plant destruction, the training and coordination of outsourced staff, the organisation of tours and events, etc. Although the conservation manager is on site, no provision is made for regular meetings between the two parties; nothing in the MoA alludes to a division of labour or the coordination of tasks-something FroK is complaining bitterly about while the everyday relationship has soured and this tension has challenged the continuation of the agreement in 2017 .

The distrust embedded in some sections of City Parks with regard to users and community engagement is visible in another document, drafted by the Stakeholder Management unit. The Volunteers Policy (JCPZ, 2015a), which guides the way in which volunteers from civil society can apply for the status that enables them to assist City Parks in maintaining parks and open spaces. The policy not only makes it clear that volunteers are to fit within City Parks' (undisclosed) existing needs, it also displays a high level of distrust of volunteers, required them to sign (three times throughout the agreement form) a commitment to the non-disclosure of any internal information on JCPZ that they might be exposed to during their volunteer work. This policy clearly does not constitute co-production, rather reaffirming City Parks' traditional mandate and dominance in what is not conceived as a 'partnership'. It is City Parks using a voluntary workforce to complement its staff in pre-existing programmes or interventions - at its discretion, and accompanied by a degree of fear of indiscretion on the part of any outsider exposed to its inner workings.

In parallel, the New Business Development unit has developed ad hoc agreements (more or less formal-letters of adoption with user groups and residents' associations; Memorandum of Agreement with the corporate sector) to formalise partnerships for the management of parks (Table 5.4). Contrasting with the complex and protracted processes of engaging with user groups around the joint management of nature reserves, the formalisation of partnerships with civil society organisations (homeowners', community, 


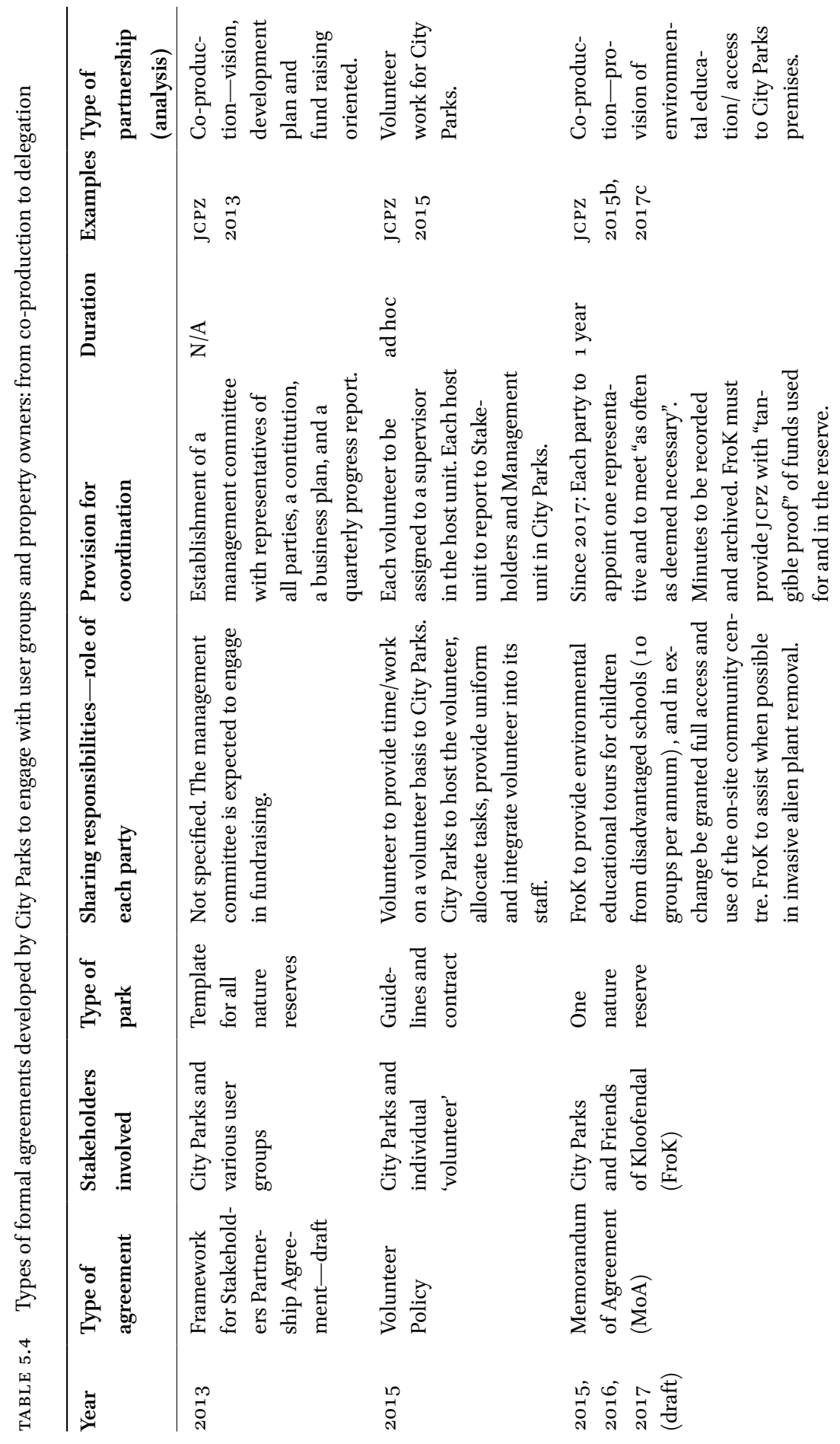




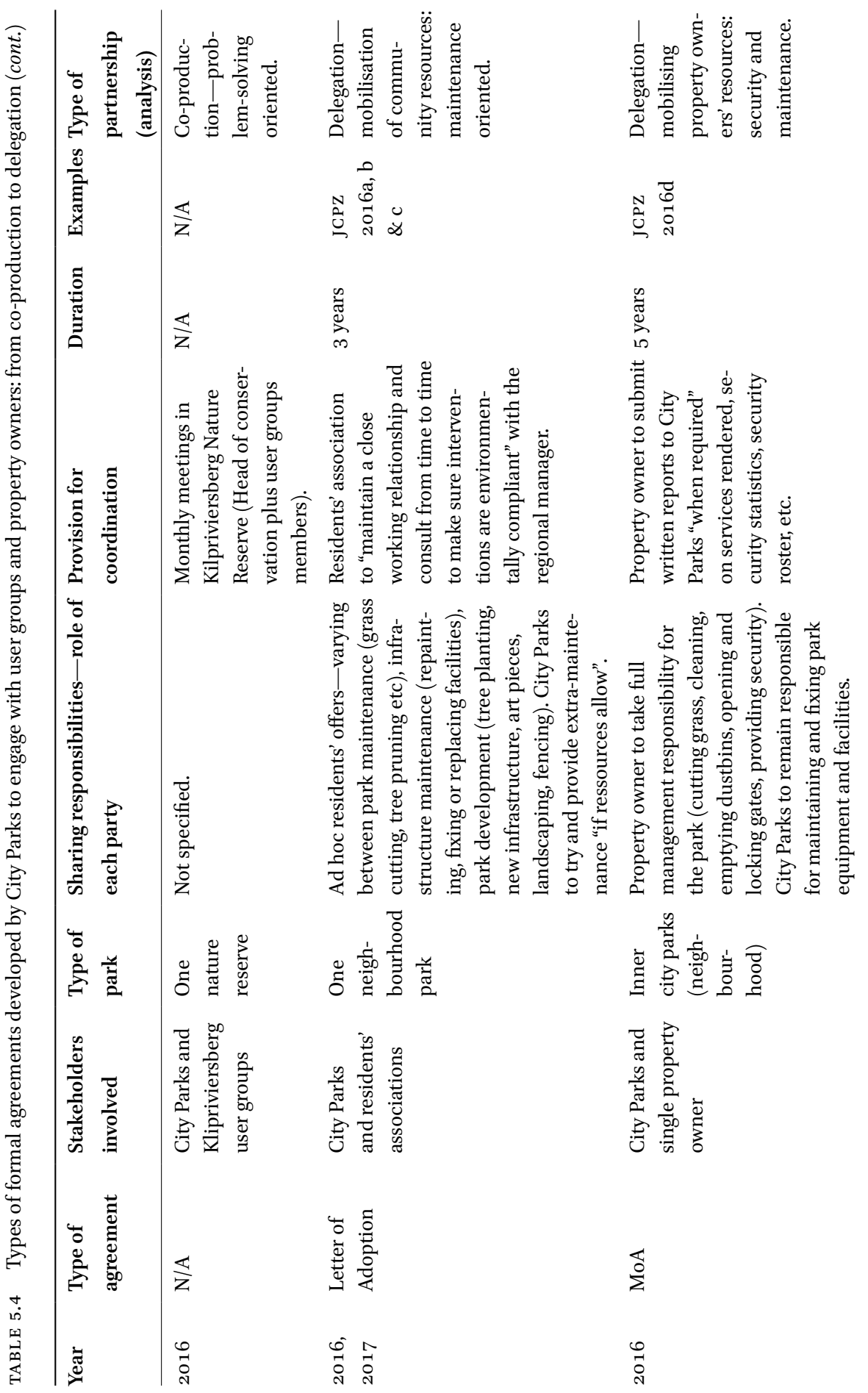




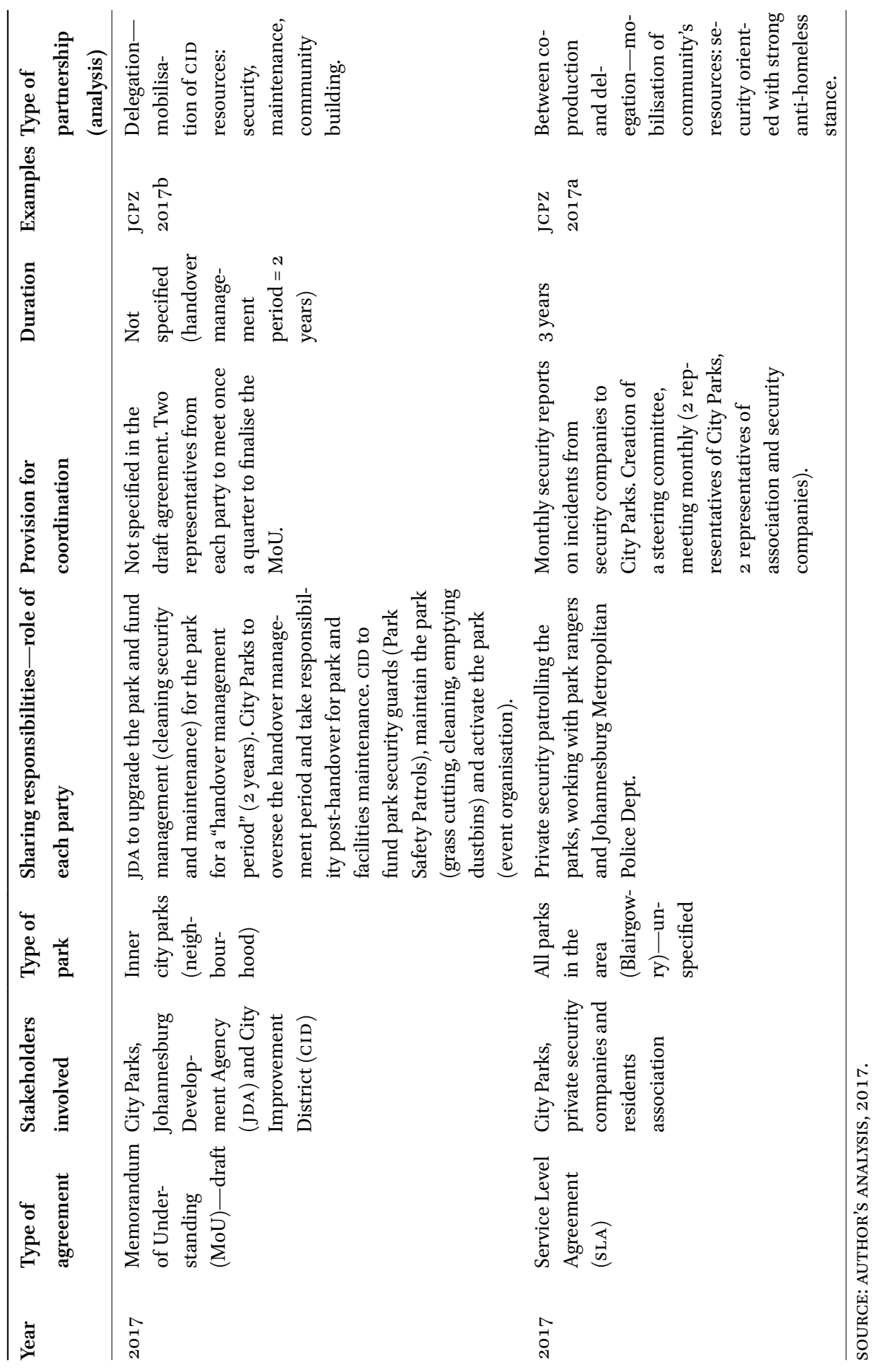


or ratepayers' associations) for neighbourhood parks' management has been straightforward. It has taken the form of 'letters of adoption' delegating tasks defined on an ad hoc basis, depending on what community organisations are willing to offer (JCPZ, 2016a, 2016b). Communities 'adopting' a specific park do so for a period of five years, and provide services from everyday park management (cleaning and grass cutting) to equipment maintenance (fixing and replacing facilities; repaving paths) to park development (new playground and security equipment, landscaping, tree planting, and the purchase of artwork).

Other, more elaborate partnerships have been developed with building owners or coalitions of property owners (in particular when they are working within City Improvement Districts) in inner city neighbourhoods as more formal Memorandums of Agreement (MoAs). In these MoAs, specific services are provided by non-state partners: park security first and foremost (and the funding of permanent security guards in the park through the CID) (JCPZ, 2017a), but also park maintenance (cleaning and grass cutting) and even at times community-building through the organisation of events (JCPZ, 2016d, 2017b).

Formal agreements are not, however, limited to the corporate sector, and letters of adoption are not always restricted to civil society organisations. For instance, a suburban residential complex has also 'adopted' a park through a letter of adoption (JCPZ, 2016c). More interestingly, a Service Level Agreement has been signed between City Parks and Blairgowrie Community Association, as well as the two main security companies patrolling the neighbourhood, to expand their security patrols to the park and regularly report to City Parks (JCPZ, 2017a). City Parks has agreed to have monthly meetings with the security company and the residents' association regarding these reports, therefore going beyond a simple delegation of security services and towards what might involve co-production. In practice, many residents' associations have negotiated with local security companies to expand their services to neighbourhood parks, but few have actually formalised this arrangement with City Parks, and most therefore do not benefit from institutionalised or regular engagement with the agency.

This set of documents consolidates various kinds of partnerships. These range from what can be seen as co-production (entailing regular meetings to 'co-decide' and co-manage, which can be understood as changing the state's practices towards accountability and problem-solving in conjunction with the partner, community, or corporate) to what constitutes degrees of delegation (where non-state agents provide a service that is not provided by City Parks, in a semi-autonomous mode with some level of reporting to City Parks but no regular meeting or joint decision-making). What the chronology and diversification of formal partnership agreements show is a rise in partnerships with the corporate sector (building owners and City Improvement Districts), especially in the inner city (the locus of mayoral regeneration efforts); and a 
shift away from complex and resource-hungry co-production towards more straightforward delegation.

The limits of the delegation model, however, are twofold. It effectively privatises park management, and does have social exclusionary effects, especially towards the more marginalised park users (Matubatuba et al., 2018). The most formal partnerships (SLAs and MoAs) have an explicit objective to evict the homeless from public parks, stating, for instance:

Unmanaged public space in Johannesburg inner city parks and open spaces makes them a haven for vagrants [sic], unemployed youth and criminals whose unlawful activities and anti-social behaviour render the essential and valuable recreational spaces in high-rise residential areas inaccessible for general public use - social, sporting, recreational.

JCPZ, 2017b, 4

JCPZ shall observe and be responsible for the following: [...] To ensure illegal street vendors and vagrancy issues when reported by any of the parties will be addressed within a reasonable time-frame as required, depending on the levels of urgency indicated.

JCPZ, 2017a

A second limitation is that these partnerships can only involve financially resourced partners, such as CIDs, building owners or middle-class residents' associations, which are able to fundraise. Less well-endowed communities, more fragmented ones, are unable to find the financial resources to sustain park management in the long run, but also therefore to demand accountability and service delivery from City Parks, unlike more resourced communities. The coordination of multiple but informal community contributions to the park, as they happen in less-structured communities, does require regular engagement with City Parks' officials, and forms of co-production, not delegation, of the management of public space.

\subsection{City Parks' Resistance to Co-production}

What explains the relative failure of co-production arrangements and their formalisation in Johannesburg? The existing, informal processes of co-production, in nature reserves in particular, have proven complex and often conflict-ridden (Mokgere, 2016). This has led City Parks to tentatively reconfigure the platform for engagement. An example of this is Klipriviersberg nature reserve, where the Forum was created in 2016 to avoid the further mediatisation of issues by very vocal associations; the Forum was, however, disbanded in mid-2017, soon after the meeting reported above. The configuration of these platforms makes them 
highly unequal, and renders debates implicitly racialised (Mokgere, 2016), with often one black, low-income City official confronted by groups of white, middle-class local leaders. The mutual and self-perpetuating racial prejudice present in these meetings has been used by some higher-placed City Parks officials to discard the issues raised by park users on this platform, and to delegitimise them as partners as only being interested in reproducing their own (white) privilege.

What this understanding does not answer to is the issue of the capacitation of park managers (here the head conservationist) to engage with and be resourced to respond to users' claims, and to drive their collective and joint framing (Jones, 2002). Granted, putting more public resources into already privileged suburban spaces (capacitating municipal staff to efficiently engage in the co-production process requires resources) is clearly politically illegitimate in post-apartheid South Africa. As the issue of co-production is framed in racial terms, and as existing practices have developed mostly in former white and middle-class areas, City Parks' internal processes of reflecting on the conditions for co-production and its institutionalisation, on changing the state's practices and mode of provision of services in conditions of scarcity, have been effectively frozen. To some extent therefore, the racialisation of social relations between City officials and existing park user groups, prevents City Parks from learning lessons from these experimental and informal practices of co-production. The political delegitimisation of (white and middle-class) park user groups, and the reluctance of City Parks to share state power with and dedicate resources to groups with perceived structural (class, racial and spatial) privilege, leads City Parks (and some officials) to block needed reflection on the transformation of its own practices.

This is ultimately damaging both for service delivery and for City Parks' key strategic objective-redressing the wrongs of the past, bridging the green divide, and developing universal access to and enjoyment of urban parks and the environment. Indeed, the absence of templates for agreements and tools for the co-management of parks, and the lack of reform of City Parks' institutions and practices, is also and perhaps even more detrimental to lowerincome communities: in townships, informal settlements, and the inner city. There, partnerships with City Parks (in the form of delegation, the partnership that is the most formalised and the easiest) are unlikely, as local communities have not organised around parks. They have not done so for a multiplicity of reasons: because parks are a scarce or new urban asset, or are not seen as the most crucial issue for collective mobilisation; because residents have got used to open spaces being hazards rather than assets (see Hadebe, 2015; Mcetywa 
et al., 2015); or because there is limited capacity or opportunity for fundraising. In these lower-income or less-organised areas, co-production championed by City Parks might be the only way to mobilise local residents, and garner local resources that might exist locally in the form of multiple uses and investment in the park, but remain fragmented and isolated.

Co-production remains a theoretical and practical frontier, worth analysing beyond radical critiques of neo-liberalising or 'governmentalising' partnerships. Much work remains to be done to unpack the technical, existential and political challenges entailed by processes of framing new rules, institutions and practices if one wants to go beyond informal pilots that are flexible but under-resourced and under-recognised, yet mobilise needed resources and provide forms of public goods in challenging environments. The question of the uneven capacity for co-production, across segregated spaces and unequal communities, remains; but co-production in this respect might be a lesser evil than delegation-practically efficient in selected spaces and with resourced partners, but more directly reproducing metropolitan inequalities and local exclusions.

Co-production involves both an existential and a technical reflection within the state. An existential reflection on the definition of the state's mandate and the selection of what it can delegate versus what needs to remain core; on the nature of City Parks' social and public objectives, and how they can be delivered, possibly by non-state agents, without compromising these objectives; on the trade-offs between sharing power and control. A technical reflection on the tools - their legality and practicality; their cost and their benefits-needed to set up and institutionalise the space for co-production. Here, the current proliferation of formats of agreement (MoAs, MoUs, SLAs, letters of adoption...) shows innovation and experiment in framing locally adapted partnerships in the absence of a broader template to guide theman effort that City Parks has at least temporarily set aside. However, in these experiments, the temptation is to go for the simplest tools-delegation rather than co-production (which would imply not only resourcing from City Parks but also a change in practice, a prioritisation of engagement and community facilitation that has not (yet?) been adopted as a strategic priority by City Parks). As Stone (2006) suggests, it is probably much easier for the state to establish and monitor market-based exchanges than it is to frame and guide the blurred, shifting, complex and personalised relationships involved in community engagement- even if delegation, far more than co-production, consolidates inequality of public provision between resourced and un-resourced communities and spaces. 
Why is the co-management of parks not working in Johannesburg? A number of elements explain this challenge. Contextual elements-as City Parks has not prioritised community engagement in its strategic objectives and has framed it in confused and often exclusively neo-liberal ways: as damage control, as income-generating, or as precarious job distribution. Organisational elements - as the mandate for community engagement lies in diverse, overlapping and competing administrative units marked by various professional and bureaucratic cultures that sometimes are resistant to change, still considering City Parks as the sole provider of services in line with its traditional public mandate, and in denial when it comes to its incapacity to deliver services on its own. But also, it needs to be acknowledged that the institutionalisation of co-production is extraordinarily complex - technically and politically - and that this complexity fuels the conservative forces within the state. It seems much easier for City Parks to delegate park management to resourced partners (at no direct cost to City Parks, and involving little change in its practices, tools and self-representation) than to put City Parks resources and energies into engaging in regular forums or committees of co-production, inventing new instruments and reshaping its own mandate, accepting the power trade-offs and skill reshuffling requested by such partnerships. These complex but productive (and possibly ultimately more efficient) paths are being experimented in Johannesburg nature reserves; but they are being blocked by a degree of racialisation of state-user groups' engagements that makes them easy to discard, and limits City Parks' ability to learn from them, refine, and institutionalise them.

The reconfiguration of this section of the state (a municipal agency that is marginalised in strategic and budgetary terms in the Johannesburg City Council) can therefore be understood as being reshaped by diverse and overlapping rationalities. The first is neo-liberal rationality and its solution set (external fundraising, use of temporary and volunteer workers, emphasis on partnerships, and protection of the brand) and modalities of bureaucratic control (quantitative KPIs). But it would not on its own suffice to explain City Parks' practices and their shift. There is secondly a degree of pragmatic rationality. Delegating park management to resourced user groups or corporates is an efficient and immediate response to a funding, staff, and skills shortage, and to the legal incapacity of the municipality to ring-fence locally raised funding (which is partly overcome through the recourse to such user groups' initiatives). It can be done simply through ready-made contracts, more readily available than complex, negotiated community agreements requiring regular 
interaction, legal innovation and joint problem-solving. Thirdly, besides the neo-liberal and pragmatic rationalities, there is still a powerful rationality constructed around the notion of 'transformation'-actively addressing the racial and social inequalities inherited from the past. This post-apartheid rationality drives budgetary choices (the emphasis on the distribution of small service contracts to individuals and collectives), but also forms of delegitimisation of existing user groups: good enough to be delegated park management in some cases, but not deemed worthy of setting up deep engagement and cooperation with, which would entail increasing, or at least restructuring (Ostrom, 1996), the state's human resources. Explicit redistributive mandates necessitating forms of centralised governance, together with racialised experiences of community engagements, therefore still strongly shape City Parks' practices and policy instruments, in resistance to the potential dynamics of co-production. Together with the neo-liberal and pragmatic rationalities, they lead, however, to the delegated management of well-resourced parks to the private sector, on the one hand, and to the limited mobilisation of state as well as non-state resources to manage parks in less-resourced areas, on the other, therefore paradoxically reproducing forms of separate and unequal management in the postapartheid city.

\section{References}

Arnstein, S. (1969) 'A Ladder of Citizen Participation', Journal of the American Planning Association, 35(4), pp. 216-224, DOI: 10.1080/01944366908977225.

Baloyi, L., M. Hunter and S. Ntombela (2015) Community engagement with the state: deciphering resident associations' influence on park management, development and conservation in the Klipriviersberg Nature Reserve, unpublished students report (Johannesburg: School of Architecture and Planning, Wits University).

Bénit-Gbaffou, C. (forthcoming) 'La participation au cœur de la gestion des parcs urbains ? Le cas de City Park à Johannesburg', submitted to Revue Internationale de Politique Comparée, August 2017.

Bénit-Gbaffou, C. (2008) 'Practices of local participation in Johannesburg — side-lining the institutional participatory channels?', Transformation: critical perspectives on Southern Africa, 66-67, pp. 1-34, DOI: https://doi.org/10.1353/trn.o.ooo3.

Bénit-Gbaffou, C. (2007) 'On conservative participation. Discussion on S. Tawa Lama-Rewal and M.H. Zerah's "middle class" mobilisation in Delhi and Mumbai', paper presented to the intenational seminar India's democratic renewal in question, Centre des Sciences Humaines, New Delhi, 9-10 July, http://hdl.handle. net/20.500.11910/5950. 
Bénit-Gbaffou, C. and E. Mkwanazi (2012) 'Expressions de la xénophobie en réunion publique et construction d'une identité de quartier: le cas de Yeoville, Johannesburg', Politique Africaine, 127, pp. 109-134. DOI: 10.3917/polaf.127.0109.

Bosaka, P. (2015) Changing practices of the state:Johannesburg City Parks and Zoo offcials' views on opportunities and challenges of community engagement, unpublished Honours report (Johannesburg: School of Architecture and Planning, Wits University).

Brenner, N. and N. Theodore (2002). 'Cities and the Geographies of "Actually Existing Neoliberalism"', Antipode, 34(3), pp. 349-379. DOI: 10.1111/1467-8330.00246.

Cooke, B. and U. Kothari (eds) (2001) Participation, the New Tyranny? (Chicago: University of Chicago Press).

Cornwall, A. (2008) 'Unpacking Participation: models, meanings and practices', Community Development Journal, 43(3), pp. 269-283, DOI: 10.1093/cdj/bsno10.

Cornwall, A. (2007) Deliberating Democracy: Scenes from a Brazilian Municipal Health Council IDS working paper No. 292 (Brighton: Institute for Development Studies).

Glaser, D. (2015) 'Uncooperative masses as a problem for substantive and participatory theories of democracy: The cases of 'people's power' (1984-6) and the 'xenophobia' (2008) in South Africa', in C. Bénit-Gbaffou (ed.) Popular Politics in South African cities. Unpacking community participation, (Cape Town: HSRC Press), pp. 139-170.

Giugni, M. (1998) 'Was It Worth the Effort? The Outcomes and Consequences of Social Movements', Annual Review of Sociology, 24, pp. 371-393, http://www.jstor.org/ stable/223486.

Graham, S. and S. Marvin (2001) Splintering Urbanism. Networked Infrastructures, Technological Mobilities and the Urban Condition. (London: Routledge).

Gupta, A. (2012) Red Tape: Bureaucracy, Structural Violence, and Poverty in India (Durham: Duke University Press).

Hadebe, S. (2015) Learning from communities' involvement in the management of park. The case of Zoo Lake and Thokoza Park, Johannesburg, unpublished Honours report (Johannesburg: School of Architecture and Planning, Wits University).

Hibou, B. (2012) La bureaucratisation du monde à l'ère néolibérale (Paris: La découverte). Hibou, B. (1999) La « décharge », nouvel interventionnisme. Politique africaine 1(73), 6-15. DOI: 10.3917/polaf.073.00o6.

Hirshman, A. (1970) Exit, Voice and Loyalty. Responses to Decline in Firms, Organisations and the State (Cambridge: Harvard University Press).

Jacobs, J. (1961) The Death and Life of Great American Cities (New York: Random House). Jaglin, S. (2008) 'Differentiating networked services in Cape Town: Echoes of splintering urbanism?', Geoforum, 39(6), pp.1897-1906, DOI:10.1016/j.geoforum.2008.04.010.

Jones, R. (2002) 'Partnerships in action: strategies for the development of voluntary community groups in urban parks', Leisure Studies, 21 (3-4), pp. 305-325, DOI: $10.1080 / 0261436022000030623$. 
Joshi, A. and M. Moore (2004) 'Institutionalised coproduction: Unorthodox public service delivery in challenging environments', The Journal of Development Studies, 40(4), pp. 31-49, DOI: 10.1080/00220380410001673184.

Krinsky, J. and M. Simonet (2017) Who cleans your park? Public work and urban governance in New York City (Chicago: University of Chicago Press).

Lascoumes, P. and P. Le Galès (2007) 'Introduction: Understanding Public Policy through Its Instruments-From the Nature of Instruments to the Sociology of Public Policy Instrumentation', Governance: An International Journal of Policy, Administration, and Institutions, 20(1), pp. 1-21, DOI: 10.1111/j.1468-0491.2007.00342.x.

MacKinnon, D. (2000) 'Managerialism, governmentality and the state: a neo-Foucauldian approach to local economic governance', Political Geography, 19(3), pp. 293-314, DOI: 10.1016/Sog62-6298(99)0oo86-4.

Matubatuba, T., S. Ndlela and C. Bénit-Gbaffou (2018) Safe but exclusive, exclusive but safe? The management of Ekhaya park by a City Improvement District in Hillbrow, Johannesburg. CUBES report (Johannesburg: School of Architecture and Planning, Wits University).

Mcetywa, N., L. Molema, T. Thaver and X. Zondo (2015) A Golf Course or an Eco Park in Mshenguville, Soweto? Exploring the extent of community influence in the park development process, unpublished students' report (Johannesburg: School of Architecture and Planning, Wits University).

Miraftab, F. (2004) 'Making Neo-liberal Governance: The Disempowering Work of Empowerment', International Planning Studies, 9(4), pp. 239-259, DOI: 10.1080/ 13563470500050130 .

Morange, M. (2015) 'Participation, neoliberal control and the voice of street traders in Cape Town - a Foucauldian perspective on "invited spaces", in C. Bénit-Gbaffou (ed.), Popular Politics in South African cities. Unpacking community participation (Cape Town: HSRC Press), pp. 171-195.

Mokgere, T. (2016). Constructing a joint vision for Johannesburg nature reserves: City Parks and users' committee engagements in Melville Koppies, Klipriviersberg and Kloofendal nature reserves, unpublished Honours research report (Johannesburg: School of Architecture and Planning, Wits University).

Ostrom, E. (1996) 'Crossing the great divide: Coproduction, synergy, and development', World Development, 24(6), pp.1073-1087, DOI: 10.1016/0305-750X(96)00023-X.

Purcell, M. (2006) 'Urban Democracy and the Local Trap', Urban Studies, 43(11), pp. 1921-1941, DOI: 10.1080/00420980600897826.

Rosol, M. (2015) 'Governing cities through participation-a Foucauldian analysis of CityPlan Vancouver', Urban Geography, 36(2), pp. 256-276, DOI: 10.108o/ 02723638.2014 .952542$.

Rosol, M. (2012) 'Community Volunteering as Neoliberal Strategy? Green Space Production in Berlin', Antipode, 44(1), pp 239-257, DOI: 10.1111/j.1467-8330.2011.00861.x. 
Rosol, M. (2010) 'Public Participation in Post-Fordist Urban Green Space Governance:

The Case of Community Gardens in Berlin', International Journal of Urban and Regional Research, 34(3), pp. 548-563. DOI: 10.1111/j.1468-2427.2010.00968.x.

Roy, A. (2009) 'Civic Governmentality: The Politics of Inclusion in Beirut and Mumbai', Antipode, 41(1), pp. 159-179, DOI: 10.1111/j.1467-8330.2008.0066o.x.

Scott, J. (1985) Weapons of the Weak: Everyday Forms of Peasant Resistance (New Haven: Yale University Press).

Stone, C. (2006) 'Power, Reform, and Urban Regime Analysis', City \& Community, 5(1), pp. 23-38, DOI: 10.1111/j.1540-6040.2006.00151.x.

Turner, J. (1976) Housing by People: Towards Autonomy in Building Environments (London: Marion Boyars).

Uitermark, J. (2005) 'The genesis and evolution of urban policy: a confrontation of regulationist and governmentality approaches', Political Geography, 24, pp. 137-163, DOI: 10.1016/j.polgeo.2004.07.009.

Watson, V. (2014) 'Co-production and collaboration in planning - the difference', Planning Theory and Practice, 15(1), pp. 62-76, DOI: 10.1080/14649357.2013.866266.

Williams, G. (2004) 'Evaluating participatory development: tyranny, power and (re) politicisation', Third World Quarterly, 25(3), pp 557-578, DOI: 10.1080/ 0143659042000191436 .

\section{Documents}

JCPZ (Johannesburg City Parks and Zoo) (2017a) Service Level Agreement (SLA) between Johannesburg City Parks and ADT Security and CSS Tactical and Blairgowry Community Association, September (Johannesburg: JCPZ).

JCPZ (2017b) Memorandum of Agreement between the Johannesburg Development Agency, the Johannesburg City Parks, and Legae La Rona \& eKhaya City Improvement Districts, draft version 1.2., 27 January (Johannesburg: JCPZ).

JCPZ (2017c) Memorandum of Agreement between Johannesburg City Parks and Zoo (JCPZ) and Friends of Kloofendaal (FrOK), September (Johannesburg: JCPZ).

JCPZ (2016a) Letter to the Blairgowrie Community Association (BCA), re: their offer to adopt the Rose Garden Park in Blairgowrie, 3 Feb (Johannesburg: JCPZ).

JCPZ (2016b) Letter to the Cresta Ext 1 and Darrenwood Ext 2 Ratepayers Association (CDRA), re their Offer to adopt the Gilla Drive Park in Cresta, 2 June (Johannesburg: $\mathrm{JCPZ})$.

JCPZ (2016c) Letter to the Gaylin Estate manager, re his Offer to adopt the Rose Garden in Northcliff, 27 January (Johannesburg: JCPZ).

JCPZ (2016d) Memorandum of Agreement between Johannesburg City Parks and AFHCO Holdings (Pty) Ltd, 8 July (Johannesburg: JCPZ). 
JCPZ (2015a) Volunteer Policy (Johannesburg:JCPZ).

JCPZ (2015b) Memorandum of Agreement between Johannesburg City Parks and Zoo (JCPZ) and Friends of Kloofendaal (FrOK), October (Johannesburg: JCPZ).

JCPZ (2014) 2013-2014 Annual Report (Johannesburg:JCPZ).

JCPZ (2013a) Corporate Strategic Plan, 2013-2018. (Johannesburg: JCPZ).

JCPZ (2013b) Framework on Stakeholder Partnership Agreement (SPA) for Joint Natural Resources Management of Natural Areas. Draft policy document (Johannesburg: $\mathrm{JCPZ})$. 